\title{
Evaluation of the Effect of Temperature on the Stability of Metal Soaps of Trichosanthes cucumerina seed oil
}

\author{
*FOLARIN, OM; ENIKANOSELU, ON
}

\author{
Chemistry Department, University of Agriculture, Abeokuta, Nigeria
}

*Corresponding author (Email: mofedara@yahoo.com)

\begin{abstract}
The thermal behaviour of metal soaps of Trichosanthes cucumerina seed oil at 433,453 and $473 \mathrm{~K}$ was investigated and the thermodynamic parameters of the decomposition process determined. The kinetics of the decomposition was studied thermogravimetrically at various temperatures. The rates of the first stage decomposition were used to assess the effect of temperature on the susceptibility of metal soaps of Trichosanthes cucumerina seed oil. The values of rate constant are of the order $10^{-2} \mathrm{~min}^{-1}$ and temperature-dependent. The enthalpy, $\Delta \mathrm{H}^{\ddagger}\left(8.8-25.0 \mathrm{kJmol}^{-}\right.$ $\left.{ }^{1}\right)$; entropy, $-\Delta S^{\ddagger}\left(0.26-0.299 \mathrm{kJmol}^{-1} \mathrm{~K}^{-1}\right)$ and free energy of activation, $\Delta \mathrm{G}^{\ddagger}\left(147.9-150.1 \mathrm{kJmol}^{-1}\right)$ for the decomposition of the metal soaps were determined. The thermodynamic values obtained showed that the system is endothermic and that the reaction process is a non-spontaneous one. @ JASEM
\end{abstract}

Seed oils are important sources of nutritional oils, industrial and pharmaceutical importance (Oderinde et al., 2009), and current emphasis on sustainable development has made it imperative to search for industrial raw materials from renewable sources. Seed oils are at the centre of this search as many useful products and industrial materials have been produced from them. One of such materials is metal carboxylates otherwise called metal soaps. Metallic soaps have been described as alkaline-earth or heavymetal long-chain carboxylates (Barth,1982), which are insoluble in water but soluble in non-aqueous solvents. The soaps of the heavy metals have important applications. Soaps of barium, cadmium, lead, zinc and calcium have found practical application as thermal stabilizers for poly(vinyl chloride) (Owen and Msayib, 1989; Bacaloglu and Fisch, 1994). Calcium and magnesium soaps are used as corrosion inhibitors in non-polar media; lead, manganese, cobalt and zinc soaps are used in paints to accelerate drying while copper soap exhibits fungicidal properties (Salager, 2002). Silver carboxylates are used as the source of silver in thermographic and photothermographic materials (Binnemans et al., 2004). Some have found use in greases, cosmetics, textiles (Egbuchunam et al., 2005).

A number of seed oils have been characterized but the vast majority have not been explored for the preparation of metal carboxylates despite being the most abundant source of carboxylic (fatty) acids. This is particularly valid for the Nigerian flora which has one of the most extensive floras in continental Africa (Oderinde et al., 1990). Many of the reports on the characterization and properties of metal soaps have been carried out on soaps prepared using pure fatty acids with little attention on the use of triglycerides, inspite of their abundance and low cost, as starting materials for the preparation of metal soaps (Egbuchunam et al., 2007). Trichosanthes cucumerina falls into this group of under utilized species of plant. Trichosanthes cucumerina var. anguina(L) Haines commonly called "Snake gourd" is a cucurbitaceous vegetable that is cultivated in gardens in Nigeria. The pulp of ripe fruits is red and a good substitute for tomato paste. The plant is well adapted to growth in high rainfall areas. It does not withstand dry soil conditions and requires a plentiful reserve of moisture in the soil; hence it grows in limited areas of the tropics and is often classified as minor cucurbitaceous (Martin, 1987). The seeds are flat, grew-brown, sculptured and narrow at one end and about $1.7 \mathrm{~cm}$ long (Tindall, 1983). With oil content of 34\%, Trichosanthes cucumerina could be classified as oilseed plant. Earlier studies (Yusuf et al., 2007) indicated that the oil is non-drying, based on its iodine value. Information on the industrial utilization of seed oil of Trichosanthes cucumerina is lacking hence the aim of this work is to prepare some metal carboxylates of the oil, subject them to high temperature and access their relative stability so as to provide information on some of their possible industrial applications.

\section{MATERIALS AND METHOD}

Preparation of the metal soaps: Metal soaps of Trichosanthes cucumerina seed oil (TSO) were prepared by metathesis in aqueous alcohol solution following the method described by Burrows et al., 1981. About $9.2 \mathrm{~g}$ of the oil was dissolved in $50 \mathrm{ml}$ of hot ethanol, followed by treatment with $20 \mathrm{ml}$ of $20 \%(\mathrm{w} / \mathrm{v})$ sodium hydroxide solution. To this mixture, $100 \mathrm{ml}$ of $30 \%(\mathrm{w} / \mathrm{v})$ solution of the appropriate metal salt was slowly added with

\footnotetext{
* Corresponding author (Email: mofedara@yahoo.com)
} 
continuous stirring. The precipitated metal soaps were washed with warm water, air-dried followed by petroleum ether and re-crystallized from benzene solution. The soaps were dried in oven at $60^{\circ} \mathrm{C}$ to constant weight. The $\mathrm{BDH}$ analar(99\%) salts used are $\mathrm{BaCl}_{2} \cdot 2 \mathrm{H}_{2} \mathrm{O} ; \quad \mathrm{CaCl}_{2} . \quad 2 \mathrm{H}_{2} \mathrm{O} ; \quad \mathrm{CuSO}_{4} \cdot 5 \mathrm{H}_{2} \mathrm{O}$ and $\mathrm{ZnSO}_{4} .7 \mathrm{H}_{2} \mathrm{O}$.

Thermal stability studies on the metal soaps: The thermal stability of the soaps was measured gravimetrically at 433,453 and $473 \mathrm{~K}$ as a function of time using procedure described by Egbuchunam et al., 2005. Typically, $0.5 \mathrm{~g}$ of the metal soap was accurately weighed into a previously weighed tube and heated in an oven at the appropriate temperature for a definite period of time $(30-120 \mathrm{mins})$. At the end of the heating time, the sample was withdrawn from the oven and cooled under running water. The residual weight of the sample was measured and the weight loss determined using the expression:

$$
\text { \%weight loss }=\frac{w_{0}-w_{1}}{w_{0}} \times 100
$$

\section{RESULTS AND DISCUSSION}

The thermal behaviour of metal soaps of Trichosanthes cucumerina seed oil at 433, 453 and $473 \mathrm{~K}$ was investigated and rates of decomposition at different intervals of time are presented in Figures 1 to 3 . The results showed that percentage weight losses increased with temperature and time. The decomposition of metal carboxylates is a multi-stage process that involved the formation carboxylic acids, metal oxides. carbondioxide and alkenes(Binnemans et al., 2004; Srinivasan and Sawant, 2003). The number and nature of the phase transitions depends on the alkyl chain length of the carboxylic acids. The formation of the gaseous and vapourizable compounds account for the observed reduction in weight during thermal decomposition. From the figures, it is evident that barium soap is the most thermally stable as it exhibited lowest rate of decomposition while copper soap is the least thermally stable of the metal soaps due to its highest rate of decomposition. .

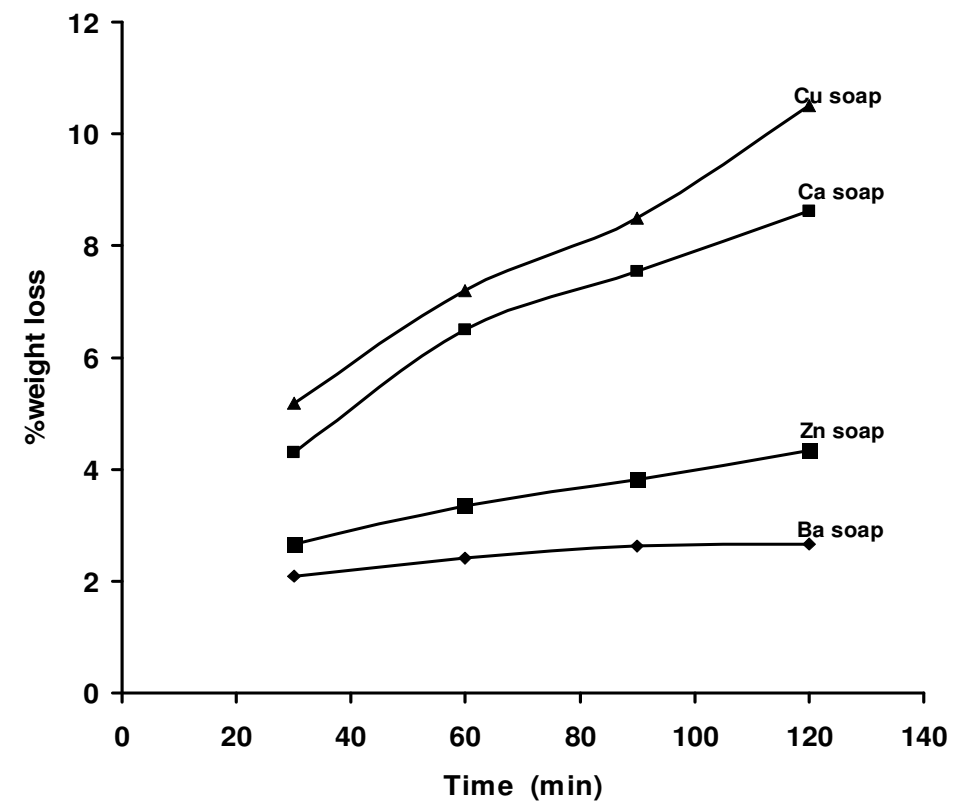

Fig 1 : Decomposition of metal soaps of Trichosanthes cucumerina seed oil at 433K

The rate of thermal decomposition of metal soaps is generally considered to follow a first order kinetics (Eghuchunam et al., 2005; Okieimen et al., 2006) and may be expressed as follows:

$$
\frac{d w}{d t}=k\left(w_{0}-w_{1}\right)
$$

where $w_{0}$ is the initial weight of the metal soap and $\mathrm{w}_{1}$ is the residual weight of the metal soap after heating while $\mathrm{k}$ is the rate constant. Rearranging and integrating ( eqn 1) gave eqn 2.

$$
\log \left(\mathrm{w}_{\mathrm{o}}-\mathrm{w}_{1}\right)=\log \mathrm{w}_{\mathrm{o}}-\frac{\mathrm{kt}}{2.303}
$$

The values of the rate constant for the decomposition of the metal soaps were obtained from the plots of 
logarithm of \%weight loss against time and the result presented in Table 1.

Table 1: Rate constants for the decomposition of metal soaps of Trichosanthes cucumerina seed oil

\begin{tabular}{|l|l|l|}
\hline Metal soap & $\begin{array}{l}\text { Temperature } \\
(\mathrm{K})\end{array}$ & $\begin{array}{l}\text { Rate constant } \\
\left(\mathrm{k} \mathrm{x} 10^{2} \mathrm{~min}^{-1}\right)\end{array}$ \\
\hline $\mathrm{Ba}$ & 433 & 1.15 \\
\cline { 2 - 3 } & 453 & 1.39 \\
\cline { 2 - 3 } & 473 & 1.45 \\
\hline $\mathrm{Ca}$ & 433 & 1.42 \\
\cline { 2 - 3 } & 453 & 1.61 \\
\cline { 2 - 3 } & 473 & 1.78 \\
\hline $\mathrm{Cu}$ & 433 & 1.40 \\
\cline { 2 - 3 } & 453 & 1.92 \\
\cline { 2 - 3 } & 473 & 2.76 \\
\hline $\mathrm{Zn}$ & 433 & 1.56 \\
\cline { 2 - 3 } & 453 & 1.62 \\
\cline { 2 - 3 } & 473 & 1.92 \\
\hline
\end{tabular}

The rate constant are of the order $10^{-2} \mathrm{~min}^{-1}$ and are also temperature-dependent with increase of $23.1 \%$, $25.4 \%, 97.1 \%$ and $26.0 \%$ within the temperature range for $\mathrm{Zn}$ soap, $\mathrm{Ca}$ soap, $\mathrm{Cu}$ soap and $\mathrm{Ba}$ soap respectively. Rate constant is a measure of energy barrier a reaction needs to overcome, the smaller the barrier, the greater the rate constant (Bruice, 1998). From the dependence of the values of the rate constant on the temperature, values for the activation energy $\left(E_{a}\right)$ of the decomposition of the metal soaps were calculated using the relationship and the result presented in Table 2.

$$
\log _{k_{1}} k_{2}=\frac{E_{a}}{2.303 R}\left(\frac{T_{2}-T_{1}}{T_{2} T_{1}}\right)
$$

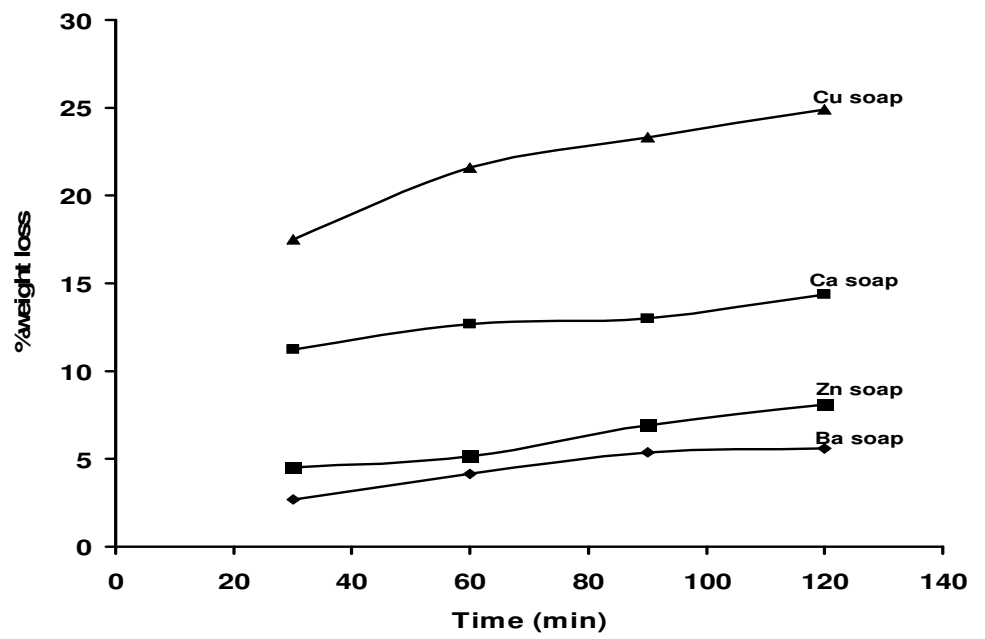

Fig 2 : Decomposition of metal soaps of Trichosanthes cucumerina seed oil at $453 \mathrm{~K}$

The activation energy for the decomposition of the metal soaps range from $12.7-28.9 \mathrm{kJmol}^{-1}$. Barium soap has the least value of $12.7 \mathrm{kJmol}^{-1}$ while copper soap has the highest value of $28.9 \mathrm{kJmol}^{-1}$. The values for zinc and calcium soaps are 14.6 and 13.5 $\mathrm{kJmol}^{-1}$ respectively. Except for $\mathrm{Cu}$ soap, the values are consistent with the observed increase in rate constants, k. These values are comparable with values reported for metal soaps of rubber seed oil
(Okieimen et al., 2006), and indicate potential industrial application of these metal soaps. The values of the enthalpy of activation, $\Delta \mathrm{H}^{\ddagger}$, for the decomposition of the metal carboxylates was calculated using the expression: $\Delta \mathrm{H}^{\ddagger}=\mathrm{E}_{\mathrm{a}}-\mathrm{RT}$ and the result presented in Table 2 . The values of the enthalpy of activation indicate that the process is endothermic.

Table 2: Thermodynamic parameters for the decomposition of metal soaps of Trichosanthes cucumerina seed oil

\begin{tabular}{|l|l|l|l|l|}
\hline $\begin{array}{l}\text { Metal } \\
\text { soap }\end{array}$ & $\begin{array}{l}\mathrm{E} \\
\left(\mathrm{kJmol}^{-1}\right)\end{array}$ & $\begin{array}{l}\Delta \mathrm{H} \\
\left(\mathrm{kJmol}^{-1}\right)\end{array}$ & $\begin{array}{l}\Delta \mathrm{G}^{\ddagger} \\
\left(\mathrm{kJmol}^{-1}\right)\end{array}$ & $\begin{array}{l}-\Delta \mathrm{S}^{\ddagger} \\
\left(\mathrm{kJmol}^{-1} \mathrm{~K}^{-1}\right)\end{array}$ \\
\hline $\mathrm{Ba}$ & 12.7 & 8.8 & 150.1 & 0.299 \\
\hline $\mathrm{Ca}$ & 13.5 & 9.6 & 149.6 & 0.296 \\
\hline $\mathrm{Cu}$ & 28.9 & 25.0 & 147.9 & 0.260 \\
\hline $\mathrm{Zn}$ & 14.6 & 10.7 & 149.3 & 0.293 \\
\hline
\end{tabular}


The true energy barrier to a reaction is given by free energy of activation, $\Delta \mathrm{G}^{\ddagger}$, (Bruice, 1998) and this was calculated using the expression: $\Delta \mathrm{G}^{\ddagger}=$ $\mathrm{RT}\left(2.303 \operatorname{logkh} / \mathrm{Tk}_{\mathrm{B}}\right)$. Some reactions are driven by a change in enthalpy, some by a change in entropy, but most by a change in both enthalpy and entropy (Bruice, 1998), the entropy of activation, $\Delta S^{\ddagger}$, for the decomposition of the metal soaps was calculated thus: $\Delta \mathrm{S}^{\ddagger}=\left(\Delta \mathrm{H}^{\ddagger}-\Delta \mathrm{G}^{\ddagger}\right) / \mathrm{T}$. The results of free energy of activation and entropy of activation for the decomposition of the metal soaps are also presented in Table 2. The values obtained for $\Delta \mathrm{G}^{\ddagger}$ and $\Delta \mathrm{S}^{\ddagger}$ show that the decomposition of the metal soaps is a non-spontaneous process and the result of free energy of activation confirmed $\mathrm{Ba}$ soap as the most stable metal soap and $\mathrm{Cu}$ soap as the least stable.

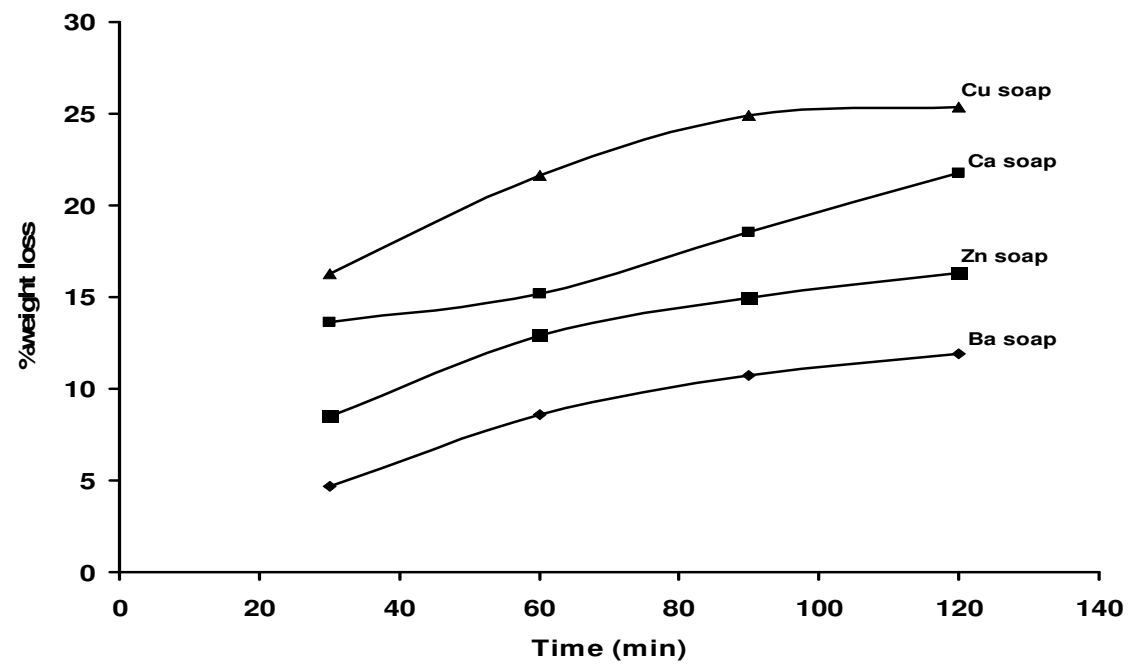

Fig 3 : Decomposition of metal soaps of Trichosanthes cucumerina seed oil at $473 \mathrm{~K}$

Conclusion: The results from this study show that metal soaps of Trichosanthes cucumerina seed oil are fairly heat stable, with barium soap being the most stable. Based on heat stability, it appears that zinc soap, calcium soap and barium soap Trichosanthes cucumerina seed oil may be suitable as stabilizer of PVC. However, other properties of additives such as miscibility and compatibility with the polymer and intended use of the polymer are essential in choosing additives in polymer formulation.

\section{REFERENCES}

Bacaloglu, R; Fisch, M. (1994). Degradation and stabilization of poly(vinyl chloride) II. Kinetics of the thermal degradation of poly(vinyl chloride). Polym Degrad. Stab. 45: 325 - 333.

Barth, T F W. (1982). Soaps In: McGraw-Hill Encyclopedia of Science and Technology. McGraw-Hill Inc. USA pp 488

Binnemans, K; Van Deun, R; Thijs, B; Vanwelkenhuysen, I; Geuens, I. (2004). Structure and mesomorphism of silver alkanoates. Chem. Mater. 16: 2021 - 2027.
Bruice, P Y. (1998). Organic Chemistry. $2^{\text {nd }}$ ed (Prentice-Hall Inc.New Jersey) pp 126.

Burrows, H D; Ellis, H A; Akanni, M S. (1981). Proceeding of the second European symposium on thermal analysis (Dallimore, D, Ed.). Heydes, London pp 29

Egbuchunam, T. O.; Okieimen, F. E; Aigbodion, A. I. (2005). Studies in the thermal stability of metal soaps of parkia seed oil. Chem. Tech. J. 1: $18-23$.

Egbuchunam, T O; Balkose, D; Okieimen, F E. (2007). Structure and thermal behaviour of polyvalent metal soaps of rubber seed oil. J. Chem. Soc. Nigeria 32(2): $107-116$

Martin, F W. (1987), CRC Handbook of tropical food crops. CRS Press Inc. Florida. pp 210 - 221.

Oderinde, R. A; Tairu, A O; Dawodu, F A; Bamiro, F O. (1990). Chemical investigation of the Cyperaceae family 2. Preliminary report on Cyperous tuberous composition . Riv. Ital. Delle

Sostanze Grasse 67, pp $301-303$. 
Oderinde, R A; Ajayi; I A; Adewuyi, A. (2009). Characterisation of seed and seed oil of Hura crepitans and kinetics of degradation of the oil during heating. EJEAFChe $201-208$.

Okieimen, F E; Egbuchunam, T O; Bakare; O I; Sogbaike, C E. (2006). Investigation on the thermal stability of $\mathrm{Ba}, \mathrm{Cd}, \mathrm{Ca}$ and $\mathrm{Zn}$ soaps of rubber seed oil. Nig J. Chem Soc. 31: 136 - 140.

Owen, E D; Msayib, K J. (1989). Catalyzed degradation of poly(vinyl chloride). III. Zinc(II) chloride catalysis. J. Polym Sci. 27: 399 - 408
Salager, J. (2002). Surfactants: Types and uses. FIRP. http:/www.nanoparticles.org Srinivasan, B R; Sawant, S C. (2003). Thermal and spectroscopic characterization of $\mathrm{Mg}(\mathrm{II})$ complexes of nitro-substituted benzoic acids. Thermochim. Acta. 402: $45-55$.

Tindall, H D. (1983), Vegetables in the tropics. Macmillan Press, London. pp 5 - 7.

Yusuf, A A; Folarin, O M; Bamiro, F. O. (2007), Chemical composition and functional properties of snake gourd(Trichosanthes cucumerina) seed flour. Nig. Food J. 25(1): 36 - 45. 